\title{
Parasitological, morphometric and genetic characterization of two Sparidae species: Diplodus sargus and Diplodus vulgaris along Tunisian coasts
}

\section{Introduction}

The Mediterranean is a hotspot of biodiversity, particularly specific. ${ }^{1}$ Indeed, it contains almost 17,000 marine species ${ }^{1}$ and characterized by a high rate of endemism. ${ }^{2,3}$ It is a marginal sea, characterized by the presence of a set of barriers providing the connection of its two basins but also the communication with other seas and oceans. Thus, the Mediterranean is connected with the Atlantic Ocean by the Strait of Gibraltar. It communicates with the Indian Ocean across the Red Sea to which it is connected by the Suez Canal. In addition, the SiculoTunisian Strait divides the Mediterranean in two basins, one oriental and the other western. ${ }^{4}$

These areas of geographical transition seem to act on a large number of species, as a physical barrier limiting gene flow and leading to differentiation between populations. ${ }^{5,6}$ Such genetic discontinuities origins in the episodes of Pleistocene glaciations and the variations sea level history. ${ }^{6}$ In addition to historical processes, these genetic differences can be attributed to other current hydrological, ecological and biological phenomena. ${ }^{7,8}$

In the Mediterranean, and particularly on the Tunisian coasts, Sparids represent one of the richest and most diverse teleost families. ${ }^{9}$ This family is represented in this area by 24 species $^{10,12} 20$ of which have been reported from Tunisian coasts..$^{13,14,15}$ The Sparidae, commonly called "the bream of the sea", are very popular fish by consumers, because of the excellent quality of their flesh, which favors the overexploitation of their stocks, especially on the coasts Tunisians. ${ }^{16}$

In this thesis, we studied the parasitologic, morphometric and genetic variability of two species of Sparidae of the genus Diplodus: the sea bream Diplodus sargus and the black-headed sar Diplodus vulgaris as well as the study of their Copepodofauna.

The study of the Copepodofauna allowed us to collect two species of parasitic Copepods, Caligus diaphanus and Clavellotis sargi on D. sargus and four species, Clavellotis sargi, Sparidicola lithognati, Lernanthropus vorax and Lernaeolophus sultanus on D. vulgaris. The analysis of global quantitative parameters of parasitism in blackheaded sar collected from Bizerte Bay and Ghar El Melh lagoon showed moderate parasitism in both types of aquatic environments. Seasonal analysis of the prevalence, mean intensity, and abundance of the four copepod species revealed that the temperature would control the development of harvested pests, while confinement of the lagoon environment would promote transmission to host and circulation in host populations.

The study of morphometric variability concerned, in addition to samples from the Tunisian coasts, a Moroccan Atlantic sample for each of the two species. Two approaches were used, traditional measures and Truss approach. The analyzes carried out allowed us to highlight a morphological variation of the samples of D. sargus between the northeastern and south eastern sectors of Tunisia as
Volume 8 Issue 3 - 2019

\author{
Myriam Kaoueche \\ Université de Tunis El Manar, Faculté des sciences de Tunis, \\ Tunisia \\ Correspondence: Myriam Kaoueche, Université de Tunis El \\ Manar, Faculté des sciences de Tunis, Tunisia, \\ Emailmyrka26@gmail.com
}

Received: December 30, 2018 | Published: June 28, 2019

well as the discrimination of the sample of the El Biban lagoon. Morphometric similarities between the Atlantic sample and the El Biban lagoon were also observed. For the species D. vulgaris, we showed a clear discrimination of the sample of Atlantic origin. The morphometric differences revealed in both species seem to be related to the environmental heterogeneity of the sampling sites.

The analysis of the genetic variability of the Tunisian populations of the two species D. sargus and D. vulgaris was approached by means of two types of markers, one biochemical (allozymes) and the other molecular (Cytochrome b). This last marker was only used for D. sargus species. In both species, the level of gene diversity observed is low. The analysis of genetic differentiation between samples from the Tunisian coast of Black-headed Sars has shown the absence of genetic structuring. This homogeneity could be the result of a large dispersion of the larval phase. With regard to the common sar, the results obtained with the two markers used, revealed a some discordance. Indeed, moderate heterogeneity has been observed in Tunisian coastal populations using allozyme markers, which is not the case with mitochondrial data. The connectivity of the studied sites, associated with the dispersive phase more or less long D. sargus larvae and the mobility of young and adults of this species represent a set of factors that would favor the mixing of the samples of the two basins, western and eastern, from the Mediterranean.

\section{Acknowledgements}

None.

\section{Conflict of Interest}

Author declares that there is no conflicts of Interest

\section{References}

1. Coll M, Piroddi C, Steenbeek J, et al. The Biodiversity of the Mediterranean Sea: Estimates, Patterns, and Threats. PLoS ONE. 2010;5(8):e11842.

2. Quignard JP, Tomasini JA. Mediterranean fish biodiversity. Biol Mar Medit.2000;7:1-66.

3. Boudouresque CF. Marine biodiversity in the mediterranean status of spicies population and communities. Sci Rep Port-Cros Nat Park Fr. 2004;20:97-146. 
4. Astraldi M, Balopoulos S, Candela J, et al. The role of straits and channels in understanding the, characteristics of Mediterranean circulation. Progress in Oceanography. 1999;44:65-108.

5. Borsa P, Naciri M, Bahri L, et al. Intraspecific zoogeography of the Mediterranean:population genetic analysis on sixteen atlanto-mediterranean species (fish and invertebrates). Vie et Milieu.1997;47:295-305.

6. Patarnello T, Volckaert FAMJ, Castilho R, et al. Pillars of Hercules: is the Atlantic-Mediterranean transition a phylogeographical break? Molecular Ecology. 2007;16:4426-4444.

7. Viñas J, Alvarado Bremer J, Pla C. Phylogeography of the Atlantic bonito (Sarda sarda) in the northern Mediterranean: the combined effects of historical vicariance, population expansion, secondary invasion, and isolation by distance. Mol Phylogenet Evol. 2004;33(1):32-42.

8. Magoulas A, Castilho R, Caetano S, et al. Mitochondrial DNA reveals a mosaic pattern of phylogeographical structure in Atlantic and Mediterranean populations of anchovy (Engraulis encrasicolus). Mol Phylogenet Evol, 2006;39(3):734-746.

9. Fischer W, Bauchot ML, Schneider M. Fiches F.A.O. d'identification des espèces pour les besoins de la pêche. Méditerranée et Mer Noir. Zone de pêche 37. FAO. Rome. 1987.
10. Bauchot ML, Hureau JC. Sparidae. In: Whitehead PJP, Bauchot ML, editors. Fishes of the North-Eastern Atlantic and theMediterranean. Unesco: Paris. 1986;883-907.

11. Golani D. Distribution of Lessepsian migrant fish in the Mediterranean. Ital. J. Zool. 1998;65:95-99.

12. Ben Othmen S. Le Sud tunisien (golfe de Gabès). Hydrologie, sédimentologie, flore et faune. Thèse Doct. 3ème Cycle. Fac Sci Tunis. UNIV. Tunis II. 1973;1-351.

13. Ghorbel M. Le pageot commun Pagellus erythrinus (Poissons, Sparidae) Ecologie et état d'exploitation dans le golfe de Gabès. Thèse 3ème cycle. UNIV. Sfax. 1996:1-170.

14. Bradai MN, Quignard JP, Bouain A, et al. Ichtyofaune autochtone et exotique des côtes tunisiennes : recensement et biogéographie. Cybium.2004;28(4):315-328.

15. Ben Meriem S, Gharbi H, Bedoui R. Les pêcheries multispécifiques du golfe de Gabès. Etat d'exploitation des principales espèces benthiques et éléments d'aménagement. Du court au long terme : échelles d'analyse et de gestion des pêches - 7ème. Forum Halieumétrique, Nantes. 2005. 